\title{
Laboratorial Aspects of Cytolytic Vaginosis and Vulvovaginal Candidiasis as a Key for Accurate Diagnosis: A Pilot Study
}

\section{Aspectos laboratoriais da vaginose citolítica e candidíase vulvovaginal como uma chave para o diagnóstico preciso: Um estudo piloto}

\author{
José Marcos Sanches ${ }^{1,2}$ Paulo César Giraldo ${ }^{10}$ Marcela Grigol Bardin ${ }^{10}$ Rose Amaral ${ }^{1(1)}$
}

Michelle Garcia Discacciati ${ }^{10}$ Luana Rossato ${ }^{3}$ (이

1 Department of Gynecology and Obstetrics, Universidade Estadual de Campinas, Campinas, SP, Brazil

2 Department of Morphology and Genetics, Escola Paulista de Medicina, Universidade Federal de São Paulo, São Paulo, SP, Brazil

${ }^{3}$ Department of Medicine, Escola Paulista de Medicina, Universidade Federal de São Paulo, São Paulo, SP, Brazil

\begin{abstract}
Address for correspondence José Marcos Sanches, Department of Morphology and Genetics, Escola Paulista de Medicina, Universidade Federal de São Paulo, São Paulo, SP, Brazil (e-mail: ms.marcossanches@gmail.com).
\end{abstract}

Rev Bras Ginecol Obstet 2020;42(10):634-641.

received January 20, 2020 accepted June 29, 2020
Objective To identify clinical, microscopic, and biochemical characteristics that differentiate cytolytic vaginosis (CV) from vulvovaginal candidiasis (VVC).

Methods The present cross-sectional study analyzed the vaginal contents of 24 nonpregnant women aged 18 to 42 years who were attended at the Genital Infections Clinic at Centro de Atenção Integral à Saúde da Mulher da Universidade Estadual de Campinas (CAISM-UNICAMP). They were diagnosed either with $(C V=8, V V C=8)$ or without vulvovaginitis or vaginal dysbiosis (controls). The socio-demographic, clinical, and gynecological data were obtained from a detailed patient interview. Samples of the vaginal contents were collected for analysis of vaginal $\mathrm{pH}$, gram stain, and specific fungal culture. The Kruskal-Wallis and Fisher exact tests were used to compare the differences between the groups. Odds ratios were used to compare the categorical variables. The significance level was considered at $p<0.05$.

Results Both women with CV and VVC had a lumpy vaginal discharge $(p=0,002)$ and vaginal hyperemia $(p=0.001)$, compared with controls. The inflammatory process was more intense in the VVC group $(p=0.001)$. In the CV group, there was statistical significance for the lactobacillus amount $(p=0.006)$, vaginal epithelium lysis $(p=0.001)$, and vaginal $\mathrm{pH}(p=0.0002)$.

Conclusion Cytolytic vaginosis and VVC diagnoses rarely differ on clinical characteristics but have different laboratorial findings. The present study highlights the importance of conducting an accurate investigation through laboratory tests rather than clinical criteria to avoid misdiagnosis.
Copyright $\odot 2020$ by Thieme Revinter

Publicações Ltda, Rio de Janeiro, Brazil
License terms

(c) (i)
$10.1055 / \mathrm{s}-0040-1715139$ ISSN 0100-7203. 


\section{Resumo}

\author{
Palavras-chave \\ - vaginose citolítica \\ - disbiose \\ - coloração de Gram \\ - bacterioscopia \\ vaginal \\ - candidíase \\ vulvovaginal
}

Objetivo Identificar características clínicas, microscópicas e bioquímicas que diferenciam a vaginose citolítica (VC) da candidíase vulvovaginal (CVV).

Métodos $\mathrm{O}$ presente estudo de corte transversal analisou o conteúdo vaginal de 24 mulheres não grávidas, com idades entre 18 e 42 anos, atendidas no ambulatório de Infecções Genitais do Centro de Atenção Integral à Saúde da Mulher da Universidade Estadual de Campinas (CAISM-UNICAMP). Elas foram diagnosticadas com (CV=8, $\mathrm{CVV}=8$ ) ou sem vulvovaginite ou disbiose vaginal (controles $=8$ ). Os dados sociodemográficos, clínicos e ginecológicos foram obtidos em uma entrevista detalhada do paciente. Amostras do conteúdo vaginal foram coletadas para análise do $\mathrm{pH}$ vaginal, coloração de Gram e cultura específica de fungos. Os testes exatos de Kruskal-Wallis e Fisher foram utilizados para comparar as diferenças entre os grupos. A razão de chances foi utilizada para comparar as variáveis categóricas. O nível de significância considerado foi de $p<0,05$.

Resultados As mulheres com VC e CVV apresentaram corrimento vaginal irregular $(p=0,002)$ e hiperemia vaginal $(p=0,001)$, em comparação aos controles. O processo inflamatório foi mais intenso no grupo $\operatorname{CVV}(p=0,001)$. No grupo VC, houve significância estatística para a quantidade de lactobacilos $(p=0,006)$, lise do epitélio vaginal $(p=0,001)$ e $\mathrm{pH}$ vaginal $(p=0,0002)$.

Conclusão Os diagnósticos de VC e CVV raramente diferem nas características clínicas, mas apresentam achados laboratoriais diferentes. O presente estudo destaca a importância de conduzir uma investigação precisa por meio de testes laboratoriais, em vez de critérios apenas clínicos, a fim de evitar erros de diagnóstico.

\section{Introduction}

Vulvovaginal candidiasis (VVC) infection caused by the Candida species affects millions of women every year and is considered the second most common vaginitis among women after bacterial vaginosis. ${ }^{1}$ It is estimated that $\sim 10$ to $15 \%$ of asymptomatic women are colonized by Candida sp and 70 to $75 \%$ of women of reproductive age experience at least one acute episode during their life. About $50 \%$ of these will have a second episode, and 5 to $10 \%$ will develop the recurrent form. ${ }^{2}$ Vulvovaginal candidiasis gives rise to much discomfort in many patients, poses a threatening problem to clinicians, and generates considerable direct and indirect economic costs associated with medication and healthcare visits, ${ }^{3}$ representing a cost estimate of $\$ 2.84$ billion in the United States alone. ${ }^{4}$ Most women will experience only one or two episodes of VVC, but there is a large, albeit poorly defined, subset that experiences multiple recurrences. ${ }^{4-7}$ Among all cases of VVC, $C$. albicans is the most common species identified among women, representing 80 to $90 \%$ of the cases, followed by non-C. albicans species, usually Candida glabrata. ${ }^{8}$ The VVC manifests itself as an inflammatory process, which, depending on the degree of local inflammation, has variable symptom intensity and is commonly misidentified as cytolytic vaginosis (CV), leading to inadequate treatment. ${ }^{9,10}$ Cytolytic vaginosis is characterized by symptoms that are very similar to those of VVC, but the laboratorial findings may be quite different. The CV criteria proposed in 1991 by Cibley and Cibley ${ }^{11}$ are: absence of Trichomonas, Gardnerella, or Candida on wet smear, an increased number of lactobacilli, paucity of leukocytes, high vaginal epithelium cytolysis, presence of a lumpy discharge, and vaginal $\mathrm{pH}$ between 3.5 and 4.5. Clinical characteristics of women with VVC include white flocculent vaginal discharge along with vulvovaginal pruritus, which may present with vulvovaginal pain and fissures. An intense inflammatory process can be observed in the vulva and/or the vagina due to the aggression on the epithelium caused by fungi. ${ }^{1}$ Both present with symptomatology that is accentuated in the premenstrual period. Vulvovaginal burning is usually more frequent in $\mathrm{CV}$, while vulvovaginal pruritus is a common symptom from women with VVC. ${ }^{12}$ However, women can have either symptom or present difficulty when reporting their symptoms to clinicians, misleading the diagnosis and, as a consequence, the treatment. ${ }^{10,13,14}$ The identification of clinical and microscopic characteristics that can differentiate CV from VVC in the outpatient setting is essential in improving the accuracy of the diagnosis, treatment, and management for women with vaginal discharge complaints. Thus, the aim of the present study was to compare the clinical and laboratorial findings of women with $\mathrm{CV}$ and VVC to define more accurate criteria to differentiate these two conditions.

\section{Methods}

\section{Selection of Subjects and Sample Collection}

In total, 42 sexually active women from 18 to 45 years old who attended the Genital Infections Outpatient Clinic of Universidade Estadual de Campinas from November 2016 to March 2017 were invited to participate in the study. Following the clinical routine of the hospital, all patients were submitted to a detailed anamnesis and gynecological 
examination. Using a sterile Dacron swab, material from the vaginal wall was collected to identify cervicovaginal diseases and to verify vaginal ecosystem conditions. Women diagnosed with endocervicitis, bacterial vaginosis, trichomoniasis, and mixed infections were ruled out. After checking for eligibility, eight women diagnosed with VVC, eight with CV and eight women with normal vulvovaginal flora and clinical characteristics (control group) were included in the study. All of the women selected were interviewed about their clinical complaints and signed the informed consent form. The local ethics committee board approved the study (process number is CAAE: 60648016.8.0000.5404).

\section{Measurement of Vaginal $\mathrm{pH}$}

This test was performed with a MERCK colorimetric tape (Merck \& Co., Inc., Kenilworth, NJ, USA) (ranging from 4.0-7.0 with variation intervals of 0.3 ) by placing the tape in the middle third of the vaginal wall for one minute and avoiding contact with the cervical mucus. After removal, the vaginal $\mathrm{pH}$ at that moment was checked according to the scale.

\section{Bacterioscopy by Gram Staining and Wet Mount Microscopy}

A sample of the vaginal contents was spread on a microscope slide and left to dry for Gram staining. It was characterized by the type of vaginal microbiota (Lactobacillus species predominance and/or other types of bacteria), the cellularity in the smear, bacterial morphology, the leukocytes, the pres- ence or absence of inflammation (absent, 1-4, or $>4$ ), and identifying pathogens as fungi. Also, the presence of hyphae was confirmed by visualization of the fungi on wet mount light microscopy of a vaginal sample. The diagnosis of bacterial vaginosis was based on the Nugent criteria., 90

\section{Fungal Culture}

A sample of the vaginal contents was collected from the middle third of the vaginal wall with a sterile swab and sown in Sabouraud's growth medium, which was sent to the Clinical Pathology Laboratory of the Clinical Hospital (HC) (microbiology laboratory), where they were processed, analyzed, and released into the hospital system.

\section{Statistical Analysis}

The Fisher exact test and odds ratio were used to compare the categorical variables, and Kruskal-Wallis compared continuous variables with abnormal distribution among the three groups studied. The significance level adopted for the statistical tests was $5 \%(p<0.05)$, with a study power calculated to $80 \%$. The SAS System for Windows version 9.2 (SAS Institute Inc, Cary, NC, USA) was used for the statistical analysis.

\section{Results}

Regarding the sociodemographic and gynecological characteristics, no statistically significant differences were observed among the three groups ( $\mathbf{- T a b l e ~} \mathbf{1}$ ).

Table 1 Sociodemographic and medical characteristics of the study subjects

\begin{tabular}{|c|c|c|c|c|c|}
\hline Characteristics & & VVC & $\mathrm{CV}$ & $\mathrm{nl}$ & $p$-value* \\
\hline Age in years** & & 36 & 34.75 & 31.13 & 0.379 \\
\hline \multirow[t]{2}{*}{ White } & & $62.5 \%(5)$ & $37.5 \%(3)$ & $62.5 \%(5)$ & \\
\hline & & & & & 0.378 \\
\hline Non-white & & $37.5 \%(3)$ & $62.5(5)$ & $37.5 \%(3)$ & \\
\hline \multirow[t]{2}{*}{ Years of schooling } & & 16.13 & 11.63 & 13.88 & 0.058 \\
\hline & 0 & $62.5 \%(5)$ & $12.5 \%(1)$ & $50 \%(4)$ & \\
\hline \multirow[t]{3}{*}{ Pregnancies } & 1 & $25 \%(2)$ & $50 \%(4)$ & $12.5 \%(1)$ & 0.283 \\
\hline & $>1$ & $12.5 \%(1)$ & $37.5 \%(3)$ & $37.5 \%(3)$ & \\
\hline & 0 & $87.5 \%(7)$ & $62.5 \%(5)$ & $100 \%(8)$ & \\
\hline \multirow[t]{2}{*}{ Abortions } & 1 & $12.5 \%(1)$ & $25 \%(2)$ & $0 \%$ & 0.273 \\
\hline & $>1$ & $0 \%$ & $12.5 \%(1)$ & $0 \%$ & \\
\hline \multirow[t]{3}{*}{ Recent sex partners (last 6 months) } & 0 & $12.5 \%(1)$ & $0 \%$ & $0 \%$ & \\
\hline & 1 & $87.5 \%(7)$ & $62.5 \%(5)$ & $87.5 \%(7)$ & 0.273 \\
\hline & $>2$ & $0 \%$ & $37.5 \%(3)$ & $12.5 \%(1)$ & \\
\hline \multirow[t]{3}{*}{ Use of condoms } & Never & $75 \%(6)$ & $37.5 \%(3)$ & $75 \%(6)$ & \\
\hline & Sometimes & $12.5 \%(1)$ & $37.5 \%(3)$ & $0 \%$ & 0.385 \\
\hline & Always & $12.5 \%(1)$ & $25 \%(2)$ & $25 \%(2)$ & \\
\hline \multirow[t]{2}{*}{ Smoking } & No & $87.5 \%(7)$ & $100 \%(8)$ & $87.5 \%(7)$ & 1.000 \\
\hline & Yes & $12.5 \%(1)$ & $0 \%$ & $12.5 \%(1)$ & \\
\hline
\end{tabular}

Abbreviations: CV: cytolytic vaginosis; nl, control group; VVC: vulvovaginal candidiasis.

* $p$-value according to the Kruskal-Wallis test for comparison of values among the 3 groups, followed by Dunn test for multiple comparisons $(p<0.05)$.

${ }^{* *}$ Age average per group. 
The frequency of vaginal hyperemia in VVC and CV was higher than in the control group, as well as the pasty discharge aspect for both conditions $(p=0.0002)$. The statistical analysis showed the same significant variables when comparing the categorical variables by groups (-Table 2 ), confirming even more precisely the results presented.

We can observe that the most prevalent complaints by the patients with VVC and CV are the existence and quantity of vaginal discharge, accompanied by dyspareunia (supplementary material 1). Vaginal itching and burning are reported by both groups, but itching and vulvar hyperemia are more related to VVC. Through the laboratorial characterizations, it was possible to confirm the diagnosis. Through the measurement of vaginal $\mathrm{pH}$, it was demonstrated that the $\mathrm{pH}$ was lower in CV (3.8-4.0) and higher in VVC (4.5-4.7) ( - Table 3).

In women with VVC, CV, and controls, the vaginal microbiota was primarily composed of Gram-positive lactobacilli.
The lysis of the vaginal epithelium and the number of lactobacilli were significantly represented in the CV group, and the presence of inflammatory process was observed in the VVC group (-Table 3 ). The vaginal bacterioscopy of the groups studied is represented by - Fig. $\mathbf{1}$. The presence of inflammatory process and Candida spp blastospores as well as of hyphae characterizing VVC are shown in - Fig. 1A and 1B. Intense lysis and increased number of lactobacilli, absence of inflammatory process, and visualization of nude nuclei, complementary to patients' complaints, accurately indicate CV (-Fig. 1C).

The integrity of the decayed epithelial cells, the absence of inflammatory process, and the normal number of lactobacilli reflect the quality of the vaginal environment and the maintenance of the basic conditions for the stability of the vagina microenvironment and is represented by - Fig. 1 D. All women in the VVC group presented positive fungal culture.

Table 2 Odds ratio analysis for categorical variables comparison of the groups of study

\begin{tabular}{|c|c|c|c|c|c|c|c|}
\hline & & $\mathrm{nl} \times \mathrm{CV}$ & $p$-value & $\mathrm{nl} \times \mathrm{VVC}$ & $p$-value & $C V \times V V C$ & $p$-value \\
\hline White & & 1.0. & 0.619 & 1.0. & 1.000 & 1.0. & 0.619 \\
\hline Non-white & & $\begin{array}{l}\text { 2.78; IC95\%: (0.37; } \\
21.03)\end{array}$ & & $\begin{array}{l}\text { 1.00; IC95\%: } \\
(0.13 ; 7.57)\end{array}$ & & $\begin{array}{l}\text { 0.36; IC } 95 \%: \\
(0.05 ; 2.73)\end{array}$ & \\
\hline \multirow{3}{*}{$\begin{array}{l}\text { Number of } \\
\text { pregnancies }\end{array}$} & 0 & 1.0. & 0.223 & 1.0. & 0.648 & 1.0. & 0.231 \\
\hline & 1 & $\begin{array}{l}\text { 16.00; IC95\%: } \\
(0.72 ; 354.78)\end{array}$ & & $\begin{array}{l}\text { 1.60; IC95\%: } \\
(0.10 ; 24.70)\end{array}$ & & $\begin{array}{l}0.10 ; \text { IC } 95 \%: \\
(0.01 ; 1.54)\end{array}$ & \\
\hline & $>1$ & $\begin{array}{l}\text { 4.00; IC95\%: (0.27; } \\
60.32)\end{array}$ & & $\begin{array}{l}\text { 0.27; IC95\%: } \\
(0.02 ; 3.65)\end{array}$ & & $\begin{array}{l}0.07 ; \text { IC } 95 \%: \\
(0.01 ; 1.51)\end{array}$ & \\
\hline \multirow{3}{*}{$\begin{array}{l}\text { Number of } \\
\text { abortions }\end{array}$} & 0 & 1.0. & 0.200 & 1.0. & 1.000 & 1.0. & 0.569 \\
\hline & 1 & $\begin{array}{l}\text { 7.73; IC95\%: (0.31; } \\
193.44)\end{array}$ & & $\begin{array}{l}3.40 ; \text { IC95\%: } \\
(0.12 ; 96.70)\end{array}$ & & $\begin{array}{l}0.36 ; \text { IC } 95 \%: \\
(0.03 ; 5.11)\end{array}$ & \\
\hline & $>1$ & $\begin{array}{l}4.64 ; \text { IC95\%: } \\
(0.16 ; 135.57)\end{array}$ & & 0 & & $\begin{array}{l}0.24 ; \text { IC } 95 \%: \\
(0.01 ; 7.21)\end{array}$ & \\
\hline \multirow{3}{*}{$\begin{array}{l}\text { Recent sex } \\
\text { partners (last } \\
6 \text { months) }\end{array}$} & 0 & 0 & 0.569 & 1.0. & 1.000 & 1.0. & 0.200 \\
\hline & 1 & 1.0 . & & $\begin{array}{l}0.33 ; \text { IC } 95 \%: \\
(0.01 ; 9.57)\end{array}$ & & $\begin{array}{l}0.45 ; \text { IC95\%: } \\
(0.02 ; 13.41)\end{array}$ & \\
\hline & $>2$ & $\begin{array}{l}\text { 4.20; IC95\%: (0.33; } \\
53.12)\end{array}$ & & $\begin{array}{l}0.11 ; \text { IC95\%: } \\
(0.01 ; 10.27)\end{array}$ & & $\begin{array}{l}0.05 ; \text { IC95\%: } \\
(0.01 ; 3.73)\end{array}$ & \\
\hline \multirow[t]{3}{*}{$\begin{array}{l}\text { Use of } \\
\text { condoms }\end{array}$} & Never & $\begin{array}{l}0.50 ; \text { IC95\%: }(0.05 ; 0 \\
5.51)\end{array}$ & 0.256 & $\begin{array}{l}2.00 ; \text { IC95\%: } \\
(0.14 ; 28.42)\end{array}$ & 1.000 & $\begin{array}{l}4.00 ; \text { IC95\%: } \\
(0.25 ; 63.95)\end{array}$ & 0.413 \\
\hline & Sometimes & $\begin{array}{l}\text { 7.00; IC95\%: (0.22; } \\
218.95)\end{array}$ & & $\begin{array}{l}5.00 ; \text { IC95\%: } \\
(0.11 ; 220.62)\end{array}$ & & $\begin{array}{l}0.67 ; \text { IC95\%: } \\
(0.03 ; 18.06)\end{array}$ & \\
\hline & Always & 1.0. & & 1.0. & & 1.0. & \\
\hline \multirow[t]{3}{*}{ Smoker } & No & 1.0. & 1.000. & 1.0. & 1.000 & 1.0. & 1.000 \\
\hline & Yes & $\begin{array}{l}0.29 ; \text { IC95\%: (0.01; } \\
8.37)\end{array}$ & & $\begin{array}{l}\text { 1.00; IC95\%: } \\
(0.05 ; 19.36)\end{array}$ & & $\begin{array}{l}\text { 3.40; IC95\%: } \\
(0.12 ; 96.70)\end{array}$ & \\
\hline & Discharge & Liquid & & 1.0. & & 0.010 & \\
\hline 1.0. & asp & 0.010 & 1.0. & 1.000 & & & \\
\hline Lumpy & $\begin{array}{l}\text { 49.00; IC95\%: } \\
(2.53 ; 948.62)\end{array}$ & & $\begin{array}{l}\text { 49.00; } \\
\text { IC95\%: (2.53; } \\
948.62)\end{array}$ & & $\begin{array}{l}\text { 1.00; IC95\%: } \\
(0.05 ; 19.36)\end{array}$ & & \\
\hline $\begin{array}{l}\text { Vulvar } \\
\text { hyperemia }\end{array}$ & Yes & 1.0. & 0.119 & 1.0. & 0.569 & 1.0. & 0.619 \\
\hline
\end{tabular}


638 Laboratorial Aspects of Cytolytic Vaginosis and Vulvovaginal Candidiasis Sanches et al.

Table 2 (Continued)

\begin{tabular}{|c|c|c|c|c|c|c|c|}
\hline & & $\mathrm{nl} \times \mathrm{CV}$ & $p$-value & $\mathrm{nl} \times \mathrm{VVC}$ & $p$-value & $C V \times V V C$ & $p$-value \\
\hline & No & $\begin{array}{l}\text { 11.67; IC95\%: } \\
(0.92 ; 147.53)\end{array}$ & & $\begin{array}{l}4.20 ; \text { IC95\%: } \\
(0.33 ; 53.12)\end{array}$ & & $\begin{array}{l}0.36 ; \text { IC95\%: } \\
(0.05 ; 2.73)\end{array}$ & \\
\hline \multirow{2}{*}{$\begin{array}{l}\text { Vaginal } \\
\text { hyperemia }\end{array}$} & Yes & 1.0. & 0.007 & 1.0. & 0.001 & 1.0 & 1.000. \\
\hline & No & $\begin{array}{l}44.20 ; \text { IC95\%: } \\
(1.80 ; 1,088.14)\end{array}$ & & $\begin{array}{l}4.20 ; \text { IC95\%: } \\
(0.33 ; 53.12)\end{array}$ & & $\begin{array}{l}\text { 2.33; IC95\%: } \\
(0.17 ; 32.58)\end{array}$ & \\
\hline \multirow[t]{2}{*}{$\begin{array}{l}\text { Lactobacilli } \\
\text { amount }\end{array}$} & Normal & 1.0 & 0.007 & 1.0 & 1.000 & $\begin{array}{l}\text { 26.71; IC95\%: } \\
\text { (1.14; 624.23) }\end{array}$ & 0.026 \\
\hline & High & $\begin{array}{l}\text { 44.20; IC95\%: } \\
(1.80 ; 1,088.14)\end{array}$ & & $\begin{array}{l}1.80 ; \text { IC95\%: } \\
(0.21 ; 15.41)\end{array}$ & & 1.0 & \\
\hline \multirow{3}{*}{$\begin{array}{l}\text { Vaginal } \\
\text { epithelium } \\
\text { lysis }\end{array}$} & Low & 1.0 & 0.001 & 1.0 & 1.000 & $\begin{array}{l}\text { 187.0; IC95\%: } \\
(3.21 ; 10884.8)\end{array}$ & 0.001 \\
\hline & Moderate & $\begin{array}{l}\text { 1.00; IC95\%: (0.01; } \\
999.99)\end{array}$ & & $\begin{array}{l}1.80 ; \text { IC95\%: } \\
(0.21 ; 15.41)\end{array}$ & & $\begin{array}{l}\text { 119.0; IC95\%: } \\
(1.95 ; 7,273.18)\end{array}$ & \\
\hline & High & $\begin{array}{l}\text { 221.00; IC95\%: } \\
(3.85 ; 12,694.7)\end{array}$ & & 0 & & 1.0 & \\
\hline \multirow{3}{*}{$\begin{array}{l}\text { Inflammatory } \\
\text { process }\end{array}$} & None & 1.0. & 1.000 & 1.0. & 0.001 & 1.0 & 0.001 \\
\hline & $1-4$ & $\begin{array}{l}0.29 \text {; IC95\%: (0.01; } \\
8.37)\end{array}$ & & $\begin{array}{l}\text { 35.0; IC95\%: } \\
(1.12 ; 1,094.7)\end{array}$ & & $\begin{array}{l}\text { 119.0; IC95\%: } \\
\text { (1.95; 7,273.2) }\end{array}$ & \\
\hline & $>4$ & 0 & & $\begin{array}{l}\text { 165.0; IC95\%: } \\
(2.81 ; 9,675.7)\end{array}$ & & $\begin{array}{l}\text { 187.0; IC95\%: } \\
(3.21 ; 10,884.8)\end{array}$ & \\
\hline \multirow[t]{5}{*}{$\mathrm{pH}$} & 3.8 & $\begin{array}{l}\text { 63.00; IC95\%: } \\
(0.98 ; 4,042.07)\end{array}$ & 0.003 & $\begin{array}{l}\text { 1.00; IC95\%: } \\
(0.01 ; 999.99)\end{array}$ & 0.239 & 1.0 & 0.013 \\
\hline & 4 & $\begin{array}{l}81.00 ; \text { IC95\%: } \\
(1.30 ; 5,046.33)\end{array}$ & & $\begin{array}{l}0.07 ; \text { IC95\%: } \\
(0.01 ; 2.33)\end{array}$ & & $\begin{array}{l}2.33 ; \text { IC95\%: } \\
(0.07 ; 76.67)\end{array}$ & \\
\hline & 4.4 & $\begin{array}{l}3.00 ; \text { IC95\%:(0.09; } \\
95.17)\end{array}$ & & $\begin{array}{l}0.20 ; \text { IC95\%: } \\
(0.01 ; 5.45)\end{array}$ & & $\begin{array}{l}\text { 7.00; IC95\%: } \\
(0.17 ; 291.34)\end{array}$ & \\
\hline & 4.5 & 1.0 & & 1.0 & & $\begin{array}{l}\text { 63.00; IC95\%: } \\
(0.98 ; 4,042.1)\end{array}$ & \\
\hline & 4.7 & 0 & & & & $\begin{array}{l}35.00 ; \text { IC95\%: } \\
(0.50 ; 2,435.7)\end{array}$ & \\
\hline \multirow[t]{3}{*}{ Nugent score } & $0-3$ & Homogeneous & No test & 1.0. & 0.077 & 1.0 & 0.077 \\
\hline & $3-6$ & sample & & $\begin{array}{l}\text { 13.22; IC95\%: } \\
\text { (0.55; 316.64) }\end{array}$ & & $\begin{array}{l}\text { 13.22; IC95\%: } \\
\text { (0.55; 316.64) }\end{array}$ & \\
\hline & $7-10$ & & & $\begin{array}{l}\text { 5.67; IC95\%: } \\
(0.19 ; 169.53)\end{array}$ & & $\begin{array}{l}\text { 5.67; IC95\%: } \\
(0.19 ; 169.53)\end{array}$ & \\
\hline
\end{tabular}

Abbreviations: CV: cytolytic vaginosis; nl, control group; VVC: vulvovaginal candidiasis. ${ }^{*} p$-value according to Fisher exact test.

${ }^{a}$ Categorical variables comparison between the control group ( $\left.\mathrm{nl}\right)$ and cytolytic vaginosis.

${ }^{b}$ Categorical variables comparison between the control group ( $\mathrm{nl}$ ) and vulvovaginal candidiasis.

${ }^{\mathrm{c} C a t e g o r i c a l ~ v a r i a b l e s ~ c o m p a r i s o n ~ b e t w e e n ~ c y t o l y t i c ~ v a g i n o s i s ~ a n d ~ v u l v o v a g i n a l ~ c a n d i d i a s i s . ~}$

Table 3 Clinical, microbiological, and biochemical aspects of vaginal content

\begin{tabular}{|c|c|c|c|c|c|}
\hline Characteristics & & VVC & VC & $\mathrm{nl}$ & p-value \\
\hline \multirow[t]{2}{*}{ Discharge aspect } & Liquid & $12.5 \%(1)$ & $12.5 \%(1)$ & $87.5 \%(7)$ & 0.002 \\
\hline & Lumpy & $87.5 \%(7)$ & $87.5 \%(1)$ & $12.5 \%(1)$ & \\
\hline \multirow[t]{2}{*}{ Vulvar hyperemia } & Yes & $37.5(3)$ & $62.5(5)$ & $12.5(1)$ & 0.171 \\
\hline & No & $62.5(5)$ & $37.5(3)$ & $82.5(7)$ & \\
\hline \multirow[t]{2}{*}{ Vaginal hyperemia } & Yes & $87.5(7)$ & $75(6)$ & 0 & 0.001 \\
\hline & No & $12.5(1)$ & $25(2)$ & $100(8)$ & \\
\hline Lactobacillus amount & Normal & $62.5 \%(5)$ & $0 \%$ & $75 \%(6)$ & 0.006 \\
\hline
\end{tabular}


Table 3 (Continued)

\begin{tabular}{|c|c|c|c|c|c|}
\hline Characteristics & & VVC & VC & $\mathrm{nl}$ & $p$-value \\
\hline & High & $37.5 \%(3)$ & $100 \%(8)$ & $25 \%(2)$ & \\
\hline \multirow[t]{3}{*}{ Vaginal epithelium lysis } & Low & $62.5 \%(5)$ & $0 \%$ & $75 \%(6)$ & \\
\hline & Moderate & $37.5 \%(3)$ & $0 \%$ & $25 \%(2)$ & 0.001 \\
\hline & High & $0 \%$ & $100 \%(8)$ & $0 \%$ & \\
\hline \multirow[t]{3}{*}{ Inflammatory process } & None & $0 \%$ & $100 \%(8)$ & $87.5(7)$ & \\
\hline & $1-4$ & $37.5 \%(3)$ & $0 \%$ & $12.5 \%(1)$ & 0.001 \\
\hline & $>4$ & $62.5 \%(5)$ & $0 \%$ & $0 \%$ & \\
\hline \multirow[t]{5}{*}{$\mathrm{pH}$} & 3.8 & $0 \%$ & $37.5 \%(3)$ & $0 \%$ & 0.0002 \\
\hline & 4 & $12.5 \%(1)$ & $50 \%(4)$ & $0 \%$ & \\
\hline & 4.4 & $12.5 \%(1)$ & $12.5 \%(1)$ & $50 \%(4)$ & \\
\hline & 4.5 & $50 \%(4)$ & $0 \%$ & $50 \%(4)$ & \\
\hline & 4.7 & $25 \%(2)$ & $0 \%$ & & \\
\hline \multirow[t]{3}{*}{ Nugent score } & $0-3$ & $50 \%(4)$ & $100 \%(8)$ & $100 \%(8)$ & \\
\hline & $03-06$ & $37.5 \%(3)$ & $0 \%$ & $0 \%$ & 0.015 \\
\hline & $07-10$ & $12.5 \%(1)$ & $0 \%$ & $0 \%$ & \\
\hline
\end{tabular}

Abbreviations: CV: cytolytic vaginosis; nl, control group; VVC: vulvovaginal candidiasis.

${ }^{*} p$-value for Kruskal-Wallis test for comparison of values among the 3 groups, followed by Dunn test for multiple comparisons $(p<0.05)$.
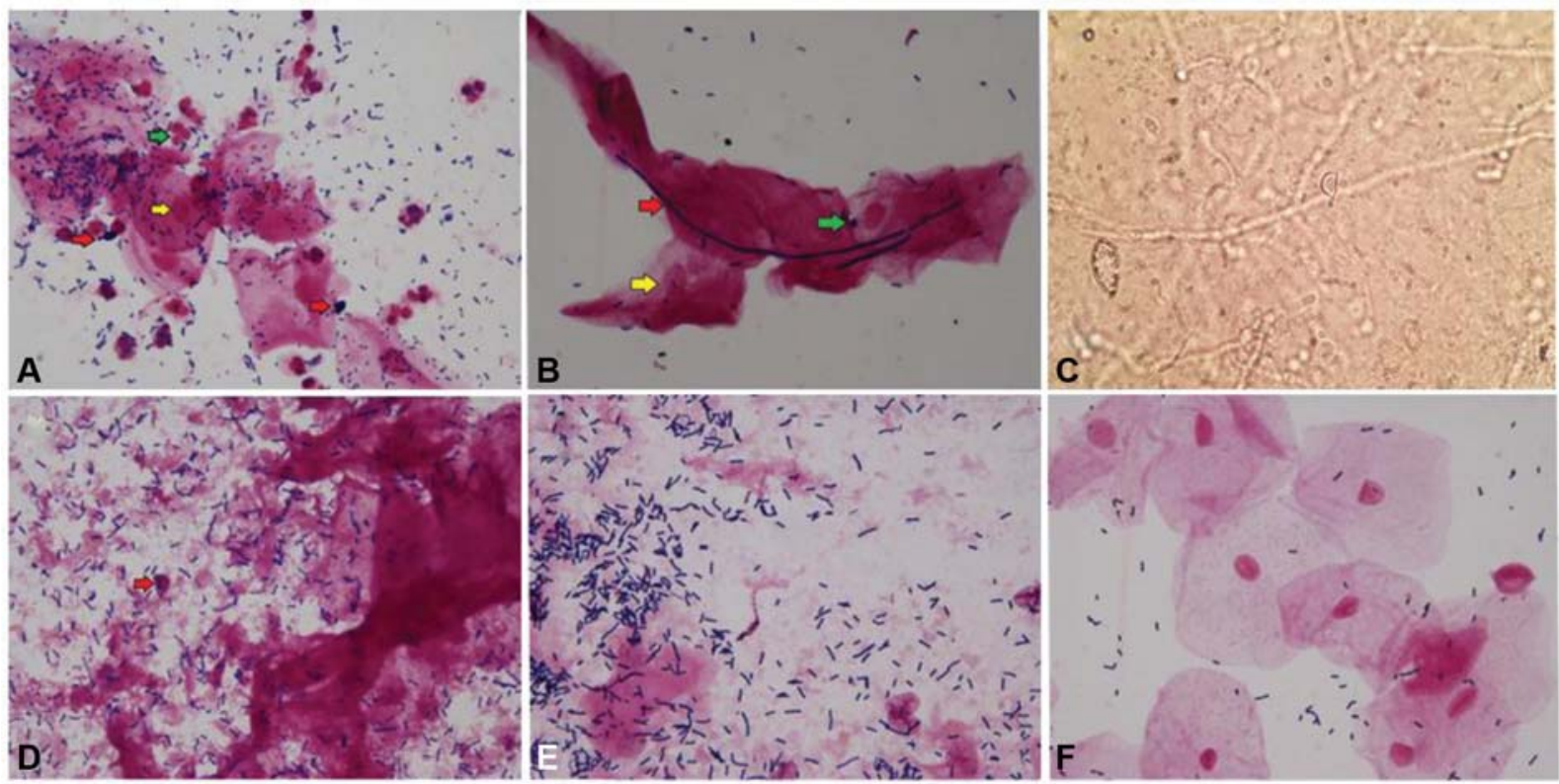

Fig. 1 Vaginal bacterioscopy of the groups. (A) Vaginal microbiota with predominance of Lactobacillus sp. with neutrophils (green arrow), presence of blastospores (red arrows), predominance of intermediate vaginal epithelial cells (yellow arrow). Diagnosis: vulvovaginal candidiasis. (B) Presence of hyphae (red arrow) and blastospores (green arrow) and predominance of intermediate vaginal epithelial cells (yellow arrow). Diagnosis: vulvovaginal candidiasis. (C) Presence of hyphae in wet mount microscopy. D and E: Vaginal microbiota with predominance and abundance of Lactobacillus sp., intense lysis in the vaginal epithelium, naked nuclei (red arrow in D) and no inflammatory process. Diagnosis: Cytolytic vaginosis. F: Normal number of lactobacilli, no inflammatory process, and predominance of intermediate vaginal epithelial cells. Diagnosis: normal. Pictures captured at the Genital Infections Outpatient Clinic of Hospital da Mulher da Universidade Estadual de Campinas, Campinas, SP, Brazil.

\section{Discussion}

The vaginal discharge complaint is one of the main factors that lead women to gynecological consultation, but it is often not so easy for the physician to make a correct diagnosis. In regard to signs and symptoms, CV is very similar to VVC. Most of the women who have CV are incorrectly diagnosed with complicated VVC refractory to treatment and, in some cases, are referenced for psychiatric treatment. ${ }^{11,14}$ Due to the fact that clinical presentation in CV and VVC is similar, a 
high level of suspicion is necessary for a correct diagnosis, especially if there is illness with a history of recurrence to specialists from several areas, symptomatology systematically refractory to various antifungal/antibiotic agents, or a diagnosis of complicated candidiasis. ${ }^{11,14-16}$ In addition to VVC, there is another pathology whose signs and symptoms are similar to CV: Döderlein lactobacillus. In this situation, there is an increase in the size of lactobacilli, which is also accompanied by a more modest increase in bacterial load. However, there is no cellular cytolysis. ${ }^{17,18}$ Microscopic examination of vaginal discharge is the pillar of the differential diagnosis among these pathologies, which is particularly important since the treatment differs according to the entity in question. ${ }^{11,13,17,18}$ In view of this, a set of clinical and laboratorial criteria must be available that, when evaluated together during the gynecological examination, can provide the physician with support for an accurate diagnosis. First, when analyzing the sociodemographic variables, we did not find significant differences among the three groups studied. We only observed a higher frequency between the number of pregnancies and women with CV, but without statistical significance, similar to what had been previously reported. ${ }^{13}$ Regarding the clinical and $\mathrm{pH}$ characteristics, we found that factors such as vaginal discharge and vaginal hyperemia were more frequent in women with $\mathrm{CV}$ and VVC, when compared with the control group. The vaginal $\mathrm{pH}$ is significantly different between women with CV and VVC. ${ }^{10}$ Some species of lactobacilli, by action of different mechanisms, are able to maintain an acidic vaginal $\mathrm{pH}$, with lactate being its main product. Acidic vaginal $\mathrm{pH}$ is essential for the protection of the vaginal epithelium against pathogenic microorganisms that develop best at basic $\mathrm{pH} .{ }^{19,20}$ A study conducted by our research group found a higher concentration of L-lactate in women with cytolytic vaginosis. ${ }^{21}$ The exacerbated growth of lactobacilli leads to higher vaginal acidity due to the action of this lactate, and the increase of this acidity can be routinely detected in the outpatient clinic through vaginal $\mathrm{pH}$ tapes. The $\mathrm{pH}$ strip with more detailed variation of color, the use of markers for the presence of leukocytes (leukocyte esterase), or cell lysis presence of histamine or other lysis marker would be relevant. When evaluating Gram-stained vaginal smears, we observed a marked cellular lysis in all women with $\mathrm{CV}$, associated with a large number of lactobacilli and an absence of polymorphonuclear cells. Similarly to these bacterioscopic results, it was found that lactobacilli overgrowth, increased cytolysis, and absence of polymorphonuclears in the cervical smears are factors associated with cytolytic vaginosis. ${ }^{13}$ However, these authors focused only on the morphological diagnosis by bacterioscopy, whereas in our study we also considered clinical signs and vaginal $\mathrm{pH}$, which are criteria that, added to bacterioscopy, could increase the accuracy of the diagnosis of $\mathrm{CV}$.

\section{Conclusion}

Cytolytic vaginosis has sufficient laboratorial characteristics to differentiate it from VVC. We can delineate bacterioscopic criteria capable of distinguishing CV and VVC: low $\mathrm{pH}$, increased number of lactobacilli, and marked cytolysis, as well as absence of fungi and polymorphonuclear scarcity in the Gram smear. Such criteria are easy and applicable in clinical practice, providing a more detailed consultation, which may allow the patient to leave the consultation with an appropriate treatment. This study highlights the importance of conducting an accurate investigation through laboratory tests rather than clinical criteria to avoid misdiagnosis.

\section{Contributions}

J. M. S.: Design, collection, analysis and interpretation of the data and writing of the article; P. C. G. design and data analysis and final revision. M. B. data analysis; R. A. collection and interpretation of the data; M. G. D. writing and revision of the article; L. R. data analysis and final revision.

\section{Conflict of Interests}

The authors have no conflict of interests to declare.

\section{Acknowledgments}

The present paper was supported by the following grant (s): Fundação de Amparo à Pesquisa do Estado de São Paulo 2017/19095-2.

\section{References}

1 Gonçalves B, Ferreira C, Alves CT, Henriques M, Azeredo J, Silva S. Vulvovaginal candidiasis: Epidemiology, microbiology and risk factors. Crit Rev Microbiol. 2016;42(06):905-927. Doi: 10.3109/ 1040841x.2015.1091805

2 Blostein F, Levin-Sparenberg E, Wagner J, Foxman B. Recurrent vulvovaginal candidiasis. Ann Epidemiol. 2017;27(09):575-582. e3. Doi: 10.1016/j.annepidem.2017.08.010

3 Zeng X, Zhang Y, Zhang T, Xue Y, Xu H, An R. Risk factors of vulvovaginal candidiasis among women of reproductive age in Xi'an: a cross-sectional study. BioMed Res Int. 2018;2018:9703754. Doi: 10.1155/2018/9703754

4 Foxman B, Barlow R, D'Arcy H, Gillespie B, Sobel JD. Urinary tract infection: self-reported incidence and associated costs. Ann Epidemiol. 2000;10(08):509-515. Doi: 10.1016/s1047-2797(00)00072-7

5 Foxman B, Muraglia R, Dietz JP, Sobel JD, Wagner J. Prevalence of recurrent vulvovaginal candidiasis in 5 European countries and the United States: results from an internet panel survey.J Low Genit Tract Dis. 2013;17(03):340-345. Doi: 10.1097/LGT.0b013e318273e8cf

6 Corsello S, Spinillo A, Osnengo G, Penna C, Guaschino S, Beltrame $A$, et al. An epidemiological survey of vulvovaginal candidiasis in Italy. Eur J Obstet Gynecol Reprod Biol. 2003;110(01):66-72. Doi: 10.1016/s0301-2115(03)00096-4

7 Richter SS, Galask RP, Messer SA, Hollis RJ, Diekema DJ, Pfaller MA. Antifungal susceptibilities of Candida species causing vulvovaginitis and epidemiology of recurrent cases. J Clin Microbiol. 2005; 43(05):2155-2162. Doi: 10.1128/jcm.43.5.2155-2162.2005

8 Sobel JD. Vulvovaginal candidosis. Lancet. 2007;369(9577):1961-1971. Doi: 10.1016/s0140-6736(07)60917-9

9 Sanches JM, Giraldo PC, Amaral R, Eberlin MN, Marques LA, Migliorini I, et al. Vaginal lipidomics of women with vulvovaginal candidiasis and cytolytic vaginosis: A non-targeted LC-MS pilot study. PLoS One. 2018;13(08):e0202401. Doi: 10.1371/journal. pone.0202401

10 Yang S, Zhang Y, Liu Y, Wang J, Chen S, Li S. Clinical significance and characteristic clinical differences of cytolytic vaginosis in recurrent vulvovaginitis. Gynecol Obstet Invest. 2017;82(02): 137-143. Doi: 10.1159/000446945 
11 Cibley LJ, Cibley LJ. Cytolytic vaginosis. Am J Obstet Gynecol. 1991; 165(4 Pt 2):1245-1249. Doi: 10.1016/s0002-9378(12)90736-x

12 Xu H, Zhang X, Yao W, Sun Y, Zhang Y. Characterization of the vaginal microbiome during cytolytic vaginosis using highthroughput sequencing. J Clin Lab Anal. 2019;33(01):e22653. Doi: $10.1002 /$ jcla.22653

13 Hu Z, Zhou W, Mu L, Kuang L, Su M, Jiang Y. Identification of cytolytic vaginosis versus vulvovaginal candidiasis. J Low Genit Tract Dis. 2015;19(02):152-155. Doi: 10.1097/lgt.0000000000000076

14 Cerikcioglu N, Beksac MS. Cytolytic vaginosis: misdiagnosed as candidal vaginitis. Infect Dis Obstet Gynecol. 2004;12(01):13-16. Doi: 10.1080/10647440410001672139

15 Mylonas I, Bergauer F. Diagnosis of vaginal discharge by wet mount microscopy: a simple and underrated method. Obstet Gynecol Surv. 2011;66(06):359-368. Doi: 10.1097/OGX.0b013e3 1822bdf31

16 Wathne B, Holst E, Hovelius B, Mårdh PA. Vaginal dischargecomparison of clinical, laboratory and microbiological findings. Acta Obstet Gynecol Scand. 1994;73(10):802-808. Doi: 10.3109/ 00016349409072509
17 Horowitz BJ, Mårdh PA, Nagy E, Rank EL. Vaginal lactobacillosis. Am J Obstet Gynecol. 1994;170(03):857-861. Doi: 10.1016/ s0002-9378(94)70298-5

18 Paavonen J. Vulvodynia-a complex syndrome of vulvar pain. Acta Obstet Gynecol Scand. 1995;74(04):243-247. Doi: 10.3109/0001634 9509024442

19 Foschi C, Salvo M, Cevenini R, Parolin C, Vitali B, Marangoni A. Vaginal lactobacilli reduce neisseria gonorrhoeae viability through multiple strategies: an in vitro study. Front Cell Infect Microbiol. 2017;7:502. Doi: 10.3389/fcimb.2017.00502

20 Mirmonsef P, Hotton AL, Gilbert D, Burgad D, Landay A, Weber $\mathrm{KM}$, et al. Free glycogen in vaginal fluids is associated with Lactobacillus colonization and low vaginal pH. PLoS One. 2014; 9(07):e102467. Doi: 10.1371/journal.pone.0102467

21 Beghini J, Linhares IM, Giraldo PC, Ledger WJ, Witkin SS. Differential expression of lactic acid isomers, extracellular matrix metalloproteinase inducer, and matrix metalloproteinase- 8 in vaginal fluid from women with vaginal disorders. BJOG. 2015; 122(12):1580-1585. Doi: 10.1111/1471-0528.13072 